\title{
Urgensi Pemahaman Kontekstual Hadis (Refleksi terhadap Wacana Islam Nusantara)
}

\author{
Tasbih \\ Universitas Islam Negeri Alauddin Makassar \\ tasbihjm@gmail.com
}

\begin{abstract}
This writing tries to show the importance of contextual understanding on hadith in order to response Islam Nusantara discourse. It is library research which takes contextual understanding on hadith and Islam Nusantara as its variables of research. The research result shown that contextual meaning is an approach which done, as an effort to analyze the meaning of hadith. it is done when there is inconsistency between the situation on a society or a certain time of decade. The hadith said that the leader should be taken from Quraisy tribe or the hadith about a nation will never find its prosperous when the leadership is given to woman are two examples which will get difficulties when it will be applied in Indonesia, as long as it is still understood textually. However, both do not find clashes when it is understood contextually. Therefore, all the Islam scientific are demanded to be ready in responding the actual problems on society life, especially in Indonesia archipelago, in order to reflect the elasticity of Islam teaching principle and method on mu'amalah and social relation issues.
\end{abstract}

\begin{abstract}
Abstrak
Tulisan ini berusaha mengungkap urgensi pemahaman kontekstual hadis dalam rangka merespon wacana Islam Nusantara. Jenis penelitian ini adalah Library Reseach Pariabel penelitian adalah pemahaman kontekstual hadis dan Islam Nusantara. Hasil penelitian menunjukkan bahwa pemahaman kontekstual adalah sebuah pendekatan yang dilakukan sebagai salah satu ijtihad dalam menelaah kandungan suatu matan hadis. Hal itu dilakukan jika ada hadis tampak ketidak sesuaiannya dengan keadaan suatu masyarakat atau kurun waktu tertentu. Hadis yang mengatakan bahwa pemimpin itu harus dari suku Quraisy atau hadis tentang tidak akan berjaya suatu kaum jika kepemimpinan itu diserahkan kepada perempuan adalah dua contoh hadis yang akan mengalami kesulitan untuk diterapkan di Indonesia jika hanya dipahami secara tekstual. Namun jika dipahami secara kontekstual kedua hadis tersebut ternyata tidak menemui benturan. Sebagai implikasi, para pengkaji Islam dituntut untuk siap mengantisipasi munculnya masalahmasalah aktual yang berkembang dalam masyarakat khususnya di nusantara, agar mencerminkan betapa elastisnya prinsip dan metode ajaran Islam dalam bidang mu'amalah dan hubungan sosial.
\end{abstract}

Keywords contextual understanding of hadidz, hadidz, Islam Nusantara, ijtihad. 


\section{A. Pendahuluan}

Islam nusantara adalah wacana yang sedang mengemuka dalam berbagai diskursus. Saat ini, istilah tersebut menimbulkan perbedaan pandangan di kalangan masyarakat, termasuk kaum intelektual di Indonesia. Perbedaan itu terjadi karena sebahagian menempuh pemahaman tekstual dan sebahagian pula menempuh pemahaman kontekstual terhadap taks-teks keagamaan. Bagi yang memahami secara tekstual akan sulit menerima istilah tersebut, sedangkan yang memahami secara kontekstual menganggap bahwa istilah tersebut adalah sesuatu yang wajar dan pantas untuk dimunculkan. Bahkan lahirnya Islam nusantara adalah hasil interppretasi kontekstual terhadap taks-teks keagamaan yang disesuaikan dengan kondisi masyarakat Indonesia.

Dalam kajian hadis, pemahaman kontekstual sulit dihindari, karena hadis Nabi saw. yang sampai kepada kaum muslimin saat ini dengan berbagai bentuk dan coraknya kadang-kadang dianggap bertentangan atau tidak sesuai dengan konteks zaman dan pemikiran modern. ${ }^{1}$ Oleh karena itu, diperlukan upaya untuk mendudukkan hadis Nabi saw. tersebut pada porsi yang semestinya.

Hadis tentunya muncul sesuai dengan posisinya sebagai penjelas al-Quran yang menjadi pedoman bagi para sahabatNabi saw. di zamannya. Apabila kondisi dan latar belakang kehidupan para sahabat tersebut berbeda, maka petunjuk-petunjuk yang diberikan oleh Nabi akan berbeda pula. Sementara itu, para sahabat pun menginterpretasikan hadis Nabi saw. tersebut sesuai dengan kapasitas mereka masing-masing, sehingga kesimpulan yang dicapai pun berbeda pula. Bila pemahaman ini diterima, maka konsekuensinya adalah bahwa sebagian hadis Nabi saw. ada yang bersifat temporal dan kontekstual. Hadis yang bersifat temporal dan kontekstual tersebut dengan sendirinya akan mencirikan kedinamisan ajaran Islam yang mampu mengakomodir budaya lokal sepanjang tidak bertentangan dengan subtansi ajaran Islam.

Sebagaimana diketahui, hadis Nabi saw disampaikan lima belas abad yang lalu di tengah-tengah masyarakat jahiliah untuk berdialog dengan mereka. Lalu, apakah pemahaman terhadap hadis pada zaman sekarang masih mengikuti pemahaman orang-orang pada zaman jahiliah? Dalam hal ini hadis tidak hanya ditujukan khusus untuk orang-orang Arab saja, melainkan untuk berdialog dengan masyarakat yang ada pada saat 
itu, sekarang, bahkan dengan generasi-generasi yang akan datang. Oleh karena itu, umat Islam khususnya di nusantara dituntut untuk memahami hadis sesuai dengan kondisi sekarang, sebagaimana orang-orang Arab Jahiliah dahulu dituntut untuk memahaminya.

Jadi, untuk menjadikan hadis tetap aktual dalam kehidupan masyarakat dewasa ini, umat Islam di nusantara tidak perlu terpaku (taklid) pada pemahaman yang diberikan ulama-ulama terdahulu. Sebab, situasi yang ada sekarang berbeda dengan situasi yang ada pada mereka. Itulah sebabnya, Abbas Mahmud al-Aqqad berkata: "Seandainya para sahabat Nabi hidup pada masa sekarang, maka pasti mereka akan menggunakan penemuan-penemuan baru, pengalaman-pengalaman sejarah yang diketahui saat ini untuk memahami al-Quran dan hadis. Dengan demikian, tidak mustahil pemahaman-pemahaman mereka sekarang akan berbeda dengan pemahaman-pemahaman mereka dahulu. ${ }^{2}$

Masyarakat Islam di nusantara adalah masyarakat yang dinamis. Perobahan itu adalah salah satu fenomena yang dinamis pula. Ini terbit dari insan yang menyokong setiap kemajuan dan perubahan yang baik dan diperlukan oleh tuntutan perkembangan insan dan masyarakat secara kontinyu. Setiap pengkaji naskah al-Quran ataupun hadis, secara umum akan merasakan betapa Islam menyokong kemajuan yang membina perubahan sosial budaya yang sehat. ia menyokong kemajuan, di samping memelihara kebebasan umum termasuk kebebasan berpikir, mencipta, mengubah dan bersikap lapang dada untuk menerima pemikiran dan peradaban lain yang waras. Juga betapa elastisnya prinsip dan metode Islam khususnya dalam bidang mu'amalah dan hubungan sosial, karena hal itu boleh disesuaikan dengan perkembangan dan kepentingan manusia yang senantiasa berkembang dan berubah sesuai tuntutan waktu dan tempat, ${ }^{3}$ seperti halnya di Indonesia. Pokok permasalahan tulisan ini adalah ingin menjawab bagaimana urgensi pemahaman konterkstual hadis dalam rangka merespon wacana Islam Nusantara? Sub-sub masalahnya adalah sebagai berikut permasalahan pertama, apa yang dimaksud pemahaman kontekstual hadis? Selanjutnya persamalahan kedua bagaimana pemahaman kontekstual hadis dalam bingkai Islam Nusantara?

\footnotetext{
${ }^{2}$ Lihat M. Quraisy Syihab, “Tafsir Kontekstual itu mutlak diperlukan”, Panji Masyarakat, No. 456, Jakarta, 21 Juli, 1987, h. 56.

${ }^{3}$ Lihat Omar Muhammad al-Tamimiy al-Syaibaniy, Falsafah al-Tarbiyah al-Islamiyah, alih bahasa Hasan Langgulung (Jakarta: Bulan Bintang, t.th.), h. 196-197.
} 


\section{B. Pemahaman kontekstual Hadis}

Yang dimaksud pemahaman kontektual hadis ialah pemaknaan dengan melihat keterkaitan antara zaman dan situasi ketika hadis ini terjadi dengan melihat keterkaitannya dengan masa sekarang. Setidaknya ada tiga arti kontekstual. Pertama, kontekstual diartikan sebagai upaya pemaknaan menanggapi masalah kini yang umumnya mendesak, sehingga arti kontekstual sama dengan situasional; kedua, pemaknaan kontekstual disamakan dengan keterkaitan masa lampau- kini - dan mendatang. Sesuatu akan dilihat makna historik lebih dahulu, makna fungsional sekarang, dan memprediksikan atau mengantisipasi makna di kemudian hari; ketiga, pemaknaan kontekstual berarti mendudukkan keterkaitan antara yang sentral (al-Qur'an) dan yang perifer (terapan). ${ }^{4}$

Dalam diskursus kajian ulum al-hadis, muncul sebuah cabang disiplin ilmu yang khusus mengkaji hal-hal yang berkaitan dengan lahirnya suatu hadis. Disiplin ilmu dimaksud ialah ilmu asbab al-wurud al-hadis. Disiplin ilmu tersebut diyakini turut membantu mengungkap makna atau kandungan sebuah hadis. Itulah sebabnya, hadis yang merupakan sesuatu yang berasal dari Nabi saw. mengandung petunjuk yang pemahamnannya perlu dikaitkan dengan peran Nabi saw. tatkala hadis itu diucapkan, ${ }^{5}$ yaitu suasana dan kejadian yang dihadapi oleh dan terjadi pada masa Nabi saw. dan sahabat-sahabatnya. Suasana pada masa Nabi saw. hidup kemungkinan berbeda dengan suasana yang dihadapi umat Islam setelah beliau wafat. Demikian juga kondisi yang dihadapi oleh masyarakat Arab pada masa Nabi saw. akan berbeda dengan kondisi masyarakat Arab setelah beliau wafat, apalagi bagi kondisi masyarakat yang non-Arab, termasuk Indonesia.

Selain itu, dalam pemahaman kontekstual hadis, hal yang penting untuk dipertimbangkan adalah eksistensi Nabi Muhammad saw. sendiri ketika menyampaikan suatu hadis. Beliau, selain sebagai Rasulullah, oleh Al-Quran juga disebut sebagai manusia biasa. Dalam Sirah-nya tampak jelas bahwa beliau hidup dalam berbagai fungsi, antara lain sebagai

\footnotetext{
${ }^{4}$ Lihat Noeng Muhajir, Metodologi Penelitian Kualitatif(Edisi III. Cet. VIII; Yogyakarta: Rake Sarasin, 1998), h. 178.

${ }^{5}$ Penjelasan yang saling melengkapi, lihat Abbas Mahmud al-Aqqad, Abqariyyah Muhammad (t.tp.: Dar al-Hilal, 1969), 90-151, Said Ramadan al-Buti, Fiqh al-Sirah (Beirut: Dar al-Fikr, 1980), h. 18, Philip K. Hitty, Histori of The Arabs (Edisi X; London: The MacMillan Press, 1974), h. 139, M. Syuhudi Ismail, "Hadis Nabi" op. cit., h.4. Mahmud Syaltut, Islam Aqidah wa Syari'ah (Kairo: Dar al-Qalam, 1966), h.510.
} 
pemimpin masyarakat, panglima perang dan hakim. ${ }^{6}$ Dalam pada itu, pemahaman hadis secara kontekstual dilakukan bila di balik teks hadis itu ada petunjuk yang kuat mengharuskan hadis yang bersangkutan dipahami dan diterapkan tidak sebagaimana makna tekstualnya. ${ }^{7}$

Untuk memahami hadis secara kontekstual, perhatian utama harus diarahkan kepada:

1. Maksud dan petunjuk Al-Quran yang merupakan pokok ajaran Islam dan mempunyai otoritas mutlak. Ini didasarkan pada fungsi hadis sebagai penjelas Al-Quran. ${ }^{8}$ Karena itu, terasa aneh dan tidak masuk akal apabila hadis sebagai penjelas, justru membawa ketentuan lain yang berbeda dan bahkan bertentangan dengan Al-Quran. Ruh AlQuran harus diletakkan sebagai tolak ukur untuk mengkaji dan memahami keakuratan maksud dan tujuan hadis. Dalam kondisi semacam ini, maka sesungguhnya tidak ada satu hadis sahih pun yang kandungannya secara substansial bertentangan dengan ayat-ayat AlQuran yang muhkamat. ${ }^{9}$ Oleh karena itu, hadis sering tampak secara zahir bertentangan dengan Al-Quran. Akan tetapi setelah diteliti dengan seksama dan dalam hubungannya dengan ayat atau hadis lainnya, ternyata hadis tersebut tidak bertentangan, dan bahkan sejalan dengan ruh syari'at yang memang demikian seharusnya.

2. Pertautan antara satu hadis dengan yang lainnya, khususnya mengenai hadis yang senada. ${ }^{10}$ Dengan cara ini dapat dimengerti maksud hadis dengan lebih jelas dan tidak ada pertentangan yang substansial di antara hadis-hadis tersebut. ${ }^{11}$ Usaha ini akan

\footnotetext{
${ }^{6}$ Lihat QS. Ali Imran : 144, al-Kahfi : 110, al-Ahzab : 40 dan al-Fath : 29.

${ }^{7}$ Lihat Muhammad Syuhudi Ismail, Hadis Nabi Yang Tekstual dan Kontekstual: Telaah Ma'ani al-Hadis tentang Ajaran Islam yang Universal, Temporal dan Lokal (Jakarta: Bulan Bintang, 1994), h. 6.

8 وانزلنا عليك الذكري لتبين لناس ما نزل اليهر ولعلهم يتفكرون (Dan kami turunkan kepadamu AlQuran, agar kamu menerangkan kepada umat manusia apa yang telah diturunkan kepada mereka dan supaya mereka memikirkan. Lihat QS. al-Nahl (16) : 44.

${ }^{9}$ Lihat Yusuf al-Qardawi, "al-Khasa al-'Ammah li al-Islm” terjemahan Rofi Munawwar dan Tajuddin dengan judul Karakteristik Islam; Kajian Analitik (Surabaya: Risalah Gusti, 1995), h. 93.

${ }^{10}$ Mengenai keharusan mempertautkan hadis dengan Al-Quran dan dengan Hadis lainnya, baca Muhammad al-Gazali, "al-Sunnah al-Nabawiyyah Bain Ahl al-Fiqh wa Ahl alHadis" terjemahan Muhammad al-Baqir dengan judul Studi Kritis atas Hadis Nabi Saw. (Bandung: Mizan: 1993), h. 149-150.

${ }^{11}$ Lihat Yusuf al-Qardawi, op. cit., h. 106.
} 
memudahkan mengetahui maksud yang sebenarnya, karena dalam keadaan yang demikian, dapat disusun kronologi pengungkapan hadis. 3. Sebab-sebab khusus yang melatarbelakangi diucapkannya sebuah hadis atau kaitannya dengan satu 'illat atau alasan tertentu, yang dinyatakan dalam hadis bersangkutan atau disimpulkan darinya. Dasarnya adalah indikasi yang mendukung ataupun yang dapat dipahami dari kejadian yang menyertainya. Ada beberapa hadis yang secara sepintas tampak umum, tetapi setelah dikaji secara seksama, ternyata ada 'illat hukum yang menyertainya. Dengan demikian, illat itulah yang sebenarnya menentukan. Selama illat itu ada, selama itu pula hukum yang bersangkutan berlaku. Dan sebaliknya, ketika illat itu hilang, maka hukum itu pun tidak berlaku lagi. الحكم يدور مع العلة (hukum itu mengikuti illatnya), ${ }^{12}$ demikian kaidah usul mengatakan. Oleh karena itu, harus diperhatikan kondisi yang melingkupi serta tempat dan untuk tujuan apa hadis itu dimunculkan. Hal ini dikarenakan sebagai mana yang diyakini umat, bahwa hadis membicarakan hal-hal yang berkenaan dengan berbagai problem, baik yang bersifat lokal, partikular maupun temporal di samping yang berkenaan dengan hal yang khash dan terinci yang tidak terdapat dalam Al-Quran.

4. Membedakan antara sarana yang berubah-ubah dan tujuan serta sasaran yang tepat. ${ }^{13}$ Percampuradukan antara sasaran yang akan dicapai dengan prasarana temporer atau lokal (yang tentunya dimaksudkan untuk mencapai tujuan tersebut) akan dapat memalingkan maksud yang sesungguhnya dari hadis bersangkutan. Dengan hanya memperhatikan bahkan memusatkan perhatian terhadap sarana-sarana yang digunakan, seolah-olah itulah yang menjadi tujuan dan sasaran hadis, akan menjadikan pemahaman yang sempit dan tentu saja tidak sejalan dengan cita-cita syari'at itu sendiri.

Seiring perkembangan dan applikasi berbagai jenis pendekatan dalam kajian Islam, maka seyogianya pemahaman terhadap hadis-hadis Nabi saw harus mempertimbangkan kondisi sosial budaya di manapun hadis itu akan diterapkan. Artinya, pendekatan kontekstual hadis adalah usaha memahami hadis berdasarkan kaitannya dengan peristiwa-peristiwa dan situasi ketika hadis itu diucapkan dan kepada siapa pula hadis itu ditujukan. Hadis Nabi saw. hendaknya tidak ditangkap makna dan

${ }^{12}$ Lihat Asmuni A. Rahman, Qaidah-Qaidah Fiqih (Jakarta: Bulan Bintang, 1976), h. 71.

${ }^{13}$ Lebih lanjut lihat Muhammad al-Gazali, op. cit., h. 163-171. 
maksudnya hanya melalui redaksi lahiriahnya tanpa mengaitkannya dengan aspek-aspek kontekstualnya.

\section{Pemahaman Kontekstual Hadis dalam Bingkai Islam Nusantara}

Islam Nusantara merupakan istilah yang unik karena memiliki karakter khas yang membedakan Islam di daerah lain. Penyebabnya adalah adanya perbedaan sejarah dan perbedaan latar belakang geografis dan latar belakang budaya yang dipijaknya. Selain itu, menurut Azyumardi Azra,Islam yang datang ke nusantara juga memiliki strategi dan kesiapan tersendiri. Kesiapan dimaksud adalah: Pertama, Islam datang dengan mempertimbangkan tradisi, tidak dilawan tetapi mencoba diapresiasi kemudian dijadikan sarana pengembangan Islam. Kedua, Islam datang tidak mengusik agama atau kepercayaan apa pun, sehingga bisa hidup berdampingan dengan mereka. Ketiga, Islam datang memilih tradisi yang sudah usang, sehingga Islam diterima sebagai tradisi dan diterima sebagai agama. Keempat, Islam menjadi agama yang mentradisi, sehingga hadirnya Islamdi nusantara ini memiliki pengaruh besar dan mendalam terhadap kehidupan bermasyarakat dan berbangsa. ${ }^{14}$

Sementara itu, proses Islamisasi tidak mempunyai awal yang pasti, juga tidak berakhir. Islamisasi lebih merupakan proses berkesinambungan yang selain mempengaruhi masa kini, juga masa yang akan datang. Islam telah dipengaruhi oleh lingkungannya, tempat Islam berpijak dan berkembang. ${ }^{15}$

Islam juga membawa perubahan sosial dan budaya, yakni memperhalus dan memperkembangkan budaya Indonesia. Penyesuaian antara adat dan syariah di berbagai daerah di Indonesia selalu terjadi, meskipun kadang-kadang dalam taraf permulaan mengalami proses pertentangan dalam masyarakat. Meskipun demikian, proses Islamisasi di berbagai tempat di Indonesia dilakukan dengan cara yang dapat diterima oleh rakyat setempat, sehingga kehidupan keagamaan masyarakat pada umumnya menunjukkan unsur campuran antara Islam dengan kepercayaan sebelumnya. Hal tersebut dilakukan oleh penyebar Islam karena di

\footnotetext{
${ }^{14}$ Lihat Azyumardi Azra. Islam Nusantara Jaringan Global dan Lokal, (Bandung; Mizan Media Utama, 2002), h.15.

${ }^{15}$ Lihat Musyrifah Sunanto, Sejarah Peradaban Islam Indonesia, (Jakarta: Raja Grafindo Persada, 2010), h. 7. Lihat juga Mundzirin Yusuf, dkk. Sejarah Peradaban Islam di Indonesia (Yogyakarta: Penerbit Pustaka, 2006), h. 56.
} 
Indonesia telah sejak lama terdapat agama (Hindu-Budha) dan kepercayaan animisme. ${ }^{16}$

Kenyataan sejarah sebagai yang disebutkan di atas, setidaknya menjadi alat bukti bahwa para penyebar agama Islam di nusantara telah berhasil memaknai secara kontekstual terhadap teks-teks keagamaan khususnya dalam bidang muamalah sehingga terasa elastis dan tidak berbenturan dengan kondisi bangsa Indonesia. Hadis yang mengatakan bahwa pemimpin itu dari suku Quraisy adalah satu contoh hadis yang sulit diterapkan di Indonesia jika hanya dipahami secara tekstual. Untuk itu diperlukan pemaknaan kontekstual agar hadis tersebut dapat dikondisikan dengan situasi Islam di nusantara.

Dalam riwayat yang dikemukakan oleh Ahmad bin Hanbal tersebut, ditemukan informasi tentang moment ketika hadis ini disampaikan. Moment itulah yang akan menjadi acuan kontekstualnya. Untuk mengetahui lebih lanjut, berikut dikemukakan teks hadis secara lengkap:

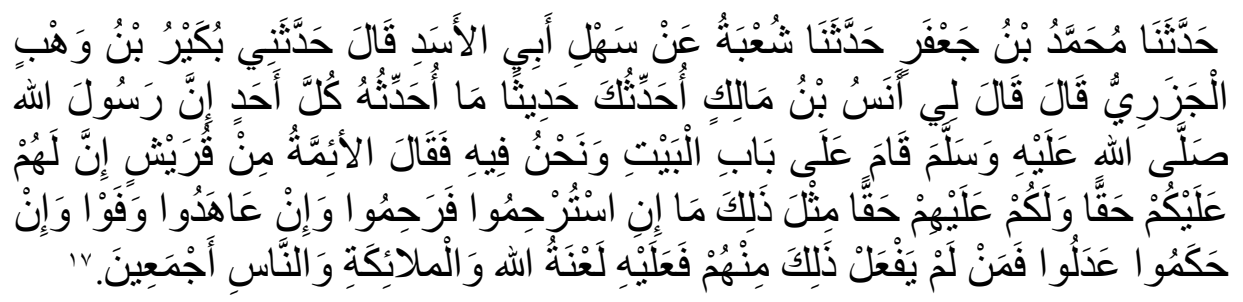

Artinya:

(Ahmad bin Hanbal berkata) Muhammad bin Ja'far telah menceritakan kepada kami, (dia berkata) Syu'bah telah menceritakan kepada kami (riwayat itu) dari Sahl Ab- al-Asad, dia berkata Bukair bin Wahb al-Jazar ${ }^{3}$ telah menceritakan kepada saya, dia berkata Anas bin $\mathrm{M} \pm$ lik telah berkata kepada saya: Saya menyampaikan kepadamu suatu hadis yang tidak disampaikan oleh seorangpun. Sesungguhnya Rasulullah saw beridri di pintu sebuah rumah yang di dalamnya kami berada, kemudian beliau bersabda; "Pemimpin itu dari suku Quraisy. Sesungguhnya kalian memiliki kewajiban terhadap mereka, dan

${ }^{16}$ Lihat P.A. Hosein Djadjadiningrat, "Islam di Indonesia”, dalam Kennet Morgan, ed., Islam Djalan Mutlak, terj. Abu Salamah, ddk. (Djakarta : PT. Pembangunan, 1963), h. 99-140. Bandingkan dengan Taufik Abdullah. Islam dan Masyarakat (Jakarta; P3ES, 1987), h. 113.

17 Ab- 'Abdillah Ahmad bin Hanbal, Musnad Ahmad, juz III (Beirut: al-Maktabat alIslami, 1978), h. 129. 
(sebaliknya) mereka memiliki kewajiban atas kalian. Mereka apabila dituntut berlaku santun, maka mereka berlaku santun, apabila mereka berjanji mereka menunaikan janji mereka, dan apabila mereka menjadi hakim mereka berlaku adil. Kalau ada dari kalangan mereka yang tidak melaksanakan yang demikian, maka terhadap mereka akan ditimpa laknat dari Allah, para malaikat dan umat manusia seluruhnya".

Hingga akhir abad kesembilan Hijriyah, pemahaman terhadap hadis ini lebih bersifat tekstual. Artinya ulama dan umat Islam memahami bahwa Quraisy merupakan syarat dan kriteria yang bersifat conditio sine quo non untuk memilih pemimpin. Bahkan pada awal abad keempat belas Hijriyah pun muncul kembali keinginan membangkitkan kharisma Quraisy sebagai simbol pemimpin umat dan sebagai syarat seorang pemimpin, yang dikemukakan oleh 'Abd al-Rahman al-Kawakibi (18491903). ${ }^{18}$ Pemikiran al-Kawakibi ini sebenarnya lebih dilatarbelakangi oleh kecenderungannya pada sistim khilafah sebagai bentuk pemerintahan dalam Islam. Beliau menghitung-hitung keunggulan dan kebaikan bangsa Arab, keunggulan Arab itu sebagai legitimasi atas skenarionya menegakkan khilafah Quraisy di Makkah. Di antara pertimbangannya: 1) Arab dan Jazirah Arab adalah tempat dilahirkannya masyarakat Islam, yang memiliki kaulitas internal yang lebih baik dibandingkan bangsabahasa lain terutama dalam harga diri, solidaritas kelompok, kepantapan, ketabahan, kesederhanaan, bebas dari prasangka rasial, keagamaan dan sektarianism; 2) masyarakat Arab yang tinggal di Jazirah Arab yang paling bersemangat dalam mempertahankan agama, menghormati risalah dan menjaga keimanan; 3) mereka adalah yang paling tua di kalangan bangsabangsa yang mempraktekkan prinsip-prinsip kesetaraan dan musyawarah, dan yang memiliki warisan kultural terbaik dalam bahasa Arab yang merupakan unsur krusial dalam pemikiran keislaman.

Pemahaman tekstualis ini baru dapat berubah menjadi pemahaman kontekstualis setelah memasuki abad kesembilan hijriyah. Adalah 'Abd al-Rahman bin Khaldun (w. 808 H./1406 M.) yang

18 Lihat Abd al-Rahman al-Kawakibi, Umm al-Qur'an (Kairo: t.p., 1931), h. 210. Pemikiran Khilafah al-Kawakibi ini kemudian juga dianut oleh Ismail al-Far-qi. Lihat Mahmudul Haq, 'Abd al-Rahman al-Kawakibi (1854-1902): A Study in Transition from Islamic Revivalism to Arab Nationalism, Bulletin Islamic Studies Aligarh University, 1964-1965, h. 63, Azyumardi Azra, Pergolakan Politik Islam: dari Fundmentalisme Modernisme Hingga Post-Modernisme (Cet. I; Jakarta: Paramadina, 1996), h. 52. 
mempelopori pemahaman kontekstual terhadap hadis ini. Dalam uraiannya tentang khilafah dan imamah, beliau tetap mengakui adanya kriteria Quraisy. Hanya saja ia berusaha merasionalkan pemahamannya dengan menyatakan bahwa kriteria Quraisy yang disebutkan oleh Nabi dalam hadis tersebut lebih bersifat simbolik. Keturunan Quraisy yang oleh Nabi dinyatakan sebagai pemegang otoritas kepemimpinan dalam Islam didasarkan pada kenyataan yang membuktikan bahwa orang Quraisylah pada saat itu yang merupakan suku Arab yang terkemuka, kuat dan tangguh. Bahkan ia dipandang sebagai pemersatu suku-suku lainnya di sekitar Hijaz. Mereka mempunyai solidaritas kelompok yang kokoh dan membuatnya paling berwibawa untuk memelihara keutuhan dan persatuan umat Islam. Oleh karena itu, pemimpin negara yang demikian itulah yang mampu mengurus negara secara efektif. Sehingga apabila ada suku lain yang lebih terkemuka dan berwibawa, maka mereka berhak memegang kepemimpinan. ${ }^{19}$ Pendapat Ibn Khaldun ini kemudian diikuti oleh ulamaulama di masanya dan masa-masa sesudahnya, termasuk Jusuf alQardawi. $^{20}$

Menurut Wahbah al-Zuhayli, kriteria harus dari Quraisy harus dilihat dari berbagai aspek dengan melihat kapasitas Quraisy ketika Nabi hidup. Mereka (Quraisy) merupakan suku yang menjadi pemuka di antara suku-suku Arab lainnya. Selaijn itu, mereka juga berhasil menjadi pengayom bagi suku-suku lainnya yang lebih kecil dan mengumpulkan potensi suku-suku yang kecil itu menjadi suatu kekuatan yang sinergis. Pemimpin-pemimpin Quraisy pada masa itu adalah pemimpin yang kharismatik, segala ucapannya selalu menjadi acuan bagi suku-suku lain. Mereka juga menguasai percaturan politik di Jazirah Arab khususnyanya di Hijaz. Dan apabila dilaksanakan voting menyangkut kepentingan politik dan kepemimpinan mereka selalu unggul. ${ }^{21}$

Dengan demikian dapat dipahami bahwa Quraisy hanya merupakan simbol dan lambang kualifikasi serta layak untuk memegang jabatan kepala negara. Pemahaman tentang Quraisy yang bersifat simbolik ini apabila dikembalikan kepada makna generik quraisy justru tidak bertentangan.

${ }^{19}$ Ibn Khaldun, Muqaddimah, h. 194, Tar ${ }^{3} k h$ Ibn Khaldun, juz I, h. 163.

20 Lihat Yusuf al-Qar«awi, "Kayfa Nata'amalu Ma'a al-Sunnah al-Nabawiyah" diterjemahkan oleh Muhammad al-Baqir dengan judul Bagaimana Memahami Hadis Nabi saw (Cet. III; Bandung: Kharizma, 1994), h. 138.

${ }^{21}$ Lihat Wahbah al-Zuhayli, op. cit, h. 698. 
Solidaritas kesukuan yang diisyaratkan dalam kepemimpinan Quraisy merupakan suatu hal yang sangat urgen dan tidak bisa dipisahkan dari Quraisy, bahkan suku-suku lainnya di Jazirah Arab. Solidaritas kesukuan sebagai perekat masyarakat Arab secara keseluruhan digambarkan Toshihiko Izutsu:

The tribe, or its subclass, the clan, was for the pre-Islamic Arabs not only the sole unit and basis of social life but represented first and foremost the highest principle of conduct, evolving a comprehensive pattern for whole of life, both individual and public. Tribal spirit was no doubt the fountainhead of all cardinal moral ideas on which Arab society was built. To respect the bond of kinship by blood more than anything else ein the word, and to act the glory of the tribe, this was by common concent a sacred duty imposed on every man, tah is every individual members of the group. ${ }^{22}$

(Sebuah suku atau sub klasnya, sautu marga, bagi orang-orang Arab sebelum Islam bukan hanya satu unit atau basis kehidupan sosial yang tunggal, tetapi yang pertama dan terpenting adalah lambang sebuah prinsip perilaku yang paling tinggi, yang menyusun suatu pola yang komprehensif bagi keseluruhan kehidupan, baik dalam konteks kehidupan individu maupun masyarakat. Semangat kesukuan dan disangsikan lagi merupakan sumber pokok semua cita moral yang atasnya masyarakat Arab dibina. Menghormati jalinan hubungan kekeluargaan yang berdasarkan ikatan darah melebih segala apapun lainnya di dunia, dan bertindak demi kemuliaan suku, yang merupakan perjanjian suci yang harus dipatuhi oleh semua orang, yakni setiap individu yang menjadi anggota kelompok yang bersangkutan).

Sejarah membuktikan bahwa tegaknya Islam pada masa itu tidak bisa dipisahkan dari semangat ashabiyah yang melekat pada orang Quraisy. Hal ini diakui oleh William Montgomery Watt:

... it was largely due to the fevor of $A_{j}$ abiyah shown by the powefull subdivision of Quraish, Abnu Hashim, who were there ready to protect him at any moment, that he could continue preaching in Mecca despite the intignation against him of the leadeing circles of

\footnotetext{
22 Toshihiko Izutsu, Ethico Religious Concept in the Koran, Montreal: McGill University Press, 1966.h. 55.
} 
Quraish. The Prophet, according toorthodox tradition, belongged by birth to this illustrious family of Mecca being one of the grandsons of Hashim. ${ }^{23}$

(. . . Hal itu sebahagian besar disebabkan oleh semangat asabiyah yang diperlihatklan oleh kaum Quraisy yang sangat kuat, Bani Hasyim. Dengan lindungan mereka ia bisa terus menyebarkan agamanya di Makkah meskipun sebagian besar pemuka Quraisy mencemohnya. Nabi Muhammad, menurut tradisi orthodox, berasal dari sebuah keluarga yang sangat terkenal di Makkah, ia cucu dari Hasyim).

Dengan demikian tampak bahwa bangsa Arab sebelum datangnya Islam merupakan bangsa berperadaban tinggi, yang disegani bangsabangsa lain. Bahasa Arab sebagai faktor terpenting solidaritas bersama, yang merupakan sumber kebanggan dan kesatuan bahasa Arab di masa lampau, kini dan mendatang. ${ }^{24}$ Solidaritas bersama yang merupakan inti sumber kejuangan Quraisy sangat dibutuhkan dalam perkembangan Islam. Solidaritas sosial merupakan salah satu aspek yang akan menetukan kejayaan Islam. Hal ini sebagaimana dikatakan oleh Ibn Khaldun, bahwa gerakan keagamaan yang tidak ditopang soilidaritas sosial tidak akan berhasil. ${ }^{25}$ Solidaritas sosial yang dipegang teguh oleh Quraisy merupakan warisan sosial yang yang sejak lama terjadi. Budaya-budaya maupun kecenderungan dan kharismatik dan semangat Quraisy masa lalu merupakan salah satu modal besar untuk membentuk konsentrasi kekuasaan. ${ }^{26}$

Dalam kajian antropologi, pemberian wewenang kepada seseorang atau sekelompok orang diklasifikasi menjadi tiga, yaitu pemberian wewenang kharismatis, tradisonal dan rasional (legal). Ketiga wewenang ini memiliki perbedaan, sesuai hubungan antara tindakan dan dasar hukum yang berlaku. Wewenang kharismatis (charismatic authority), merupakan wewenang yang didasarkan pada kharisma, berupa kemampuan khusus yang ada pada diri seseorang yang melekat pada orang tersebut karena anugerah Tuhan Yang Maha Kausa. Wewenang ini akan

${ }^{23}$ William Motgomery Watt, Muhammad at Mecca (London: Oxford Universiry Press, 1953), h. 18.

${ }^{24}$ Edmund Rabbath, Unit Syrienne et Devenir Arabe (Paris, t.p, 1937), h. 43.

${ }^{25}$ Lihat Ibn Khaldun, Muqaddimah, h. 155-156.

${ }^{26}$ Lihat Joseph Schumpeter, Imperialism and Social Classes (New York: Meridian, 1955), h. 111. 
tetap bertahan selama dapat dibuktikan keampuannya oleh masyarakat. Wenang ini dimiliki oleh para nabi dan rasul, tokoh terkemuka dalam sejarah. Wewenang ini tidak diatur oleh kaidah, baik yang tradisional maupun yang rasional. ${ }^{27}$ Wewenang tradional (traditioal authority) dimiliki oleh seseorang maupun kelompok, yang disebabkan bukan karena adanya kemampuan khusus, akan tetapi karena adanya kekuasaan dan wewenang yang melembaga dan bahkan menjiwai masyarakat. Dengan kata lain, lamanya memegang tampuk kekuasaan, sehingga masyarakat percaya dan mengakui kekuasaannya. ${ }^{28}$ Wewenang rasional (legal authority) didasarkan pada sistim hukum yang berlaku dalam masyarakat

Apabila dikaitkan dengan otoritas kepemimpian dalam Islam, maka kepemimpinan Nabi saw, merupakan wewenang kharismatik. Adapun otoritas yang kemudian diserahkan kepada Quraisy, maka hal tersebut terkait dengan pemahaman terhadap matan hadis, apakah tekstual atau kontekstual. Apabila hadis dipahami secara tekstual, otoritas Quraisy adalah otoritas tradisional, sebaliknya apabila hadis dipahami secara kontekstual, dalam pengertian bahwa Quraisy bersifat simbolik pemberian wewenang yang sebenarnya bersifat rasional.

Pemahaman kontekstual lain kemudian dikemukakan oleh $\mathrm{M}$. Syuhudi Ismail (w. 1995 M). Berangkat dari pola pikir yang melihat dan memahami hadis Nabi kemudian membedakan antara hadis-hadis yang bersifat temporal lokal dan ajaran Islam yang bersifat universal yang dikaitkan dengan fungsi Nabi, maka beliau bependapat bahwa kandungan hadis dinyatakan oleh Nabi dalam kapasitasnya sebagai kepala negara atau pemimpin masyarakat. Indikasi (qarinah) yang menjadi dasar pertimbangannya adalah ketetapan Nabi yang bersiafat primordial yang sangat mengutamakan suku Quraisy. Menurutnya, prioritas bagi Quraisy berupa pemberian otoritas dalam kepemimpinan bukan ajaran dasar dari agama Islam yang dibawa oleh Nabi, melainkan ajaran dasar yang bersifat temporal. ${ }^{29}$ Pemahaman "temporal" kandungan hadis ini juga dinaut oleh Ibn Taimiyah (w. 728 H./1328 M.), yang menolak syarat Quraisy ini, sebagai bertentangan dengan semangat egalitarian yang diajarkan oleh Islam. Lebih lanjut beliau mengatakan bahwa doktrin ini hanya berlaku

\footnotetext{
${ }^{27}$ Max Weber, Types of Authority, dalam Lewis A. Coser dan bernard Rosenberg (Eds), Social Theory (2 ${ }^{\text {nd }}$ Edition: New York: The mAcMillan Company, 1964), h. 244.

$28 \mathrm{Ibid}$, h. 61.

${ }^{29}$ M. Syuhudi Ismail, Hadis Nabi yang Tekstual dan Kontekstual: Telaah Ma'ani alHad $^{3}$ ts tentang Ajaran Islam yang Universal, Temporal dan Lokal (Cet. I; Jakarta: Bulan Bintang, 1994), h. 40-41.
} 
pada fase khulafa' al-rasyidin. ${ }^{30}$ Namun pendapat yang dikemukakan Ibn Taimiyah yang terakhir ini lemah, sebab dalam matan hadis tidak ditemukan adanya qarinah (indikasi) yang menyebutkan temporalnya hadis ini hanya hingga pada fase khulafa' al-rasyidin. Demikian pula pemaknaan tekstual terhadap hadis tidak hanya terbatas pada fase khulafa' al-rasyidin, bahkan hingga hancurnya Bahdad oleh Hulagu Khan (1258), dinasti Mamalik dan beberapa dinasti kecil lainnya masih mengakui otoritas Quraisy, terbukti dalam hubungan antara kerajaan Abbasiyah dengan beberapa kerajaan kecil yang ada di masanya mendudukkan khilafah 'Abbasiyah sebagai spritual power untuk mengesahkan eksistensi mereka berdasarkan legalitas syari'at (justifikasi syar'i). Justifikasi syar'i ini berdasar pada keyakinan terhadap makna tekstual hadis tentang otoritas kepemimpinan Quraisy.

Pertentangan antara ruh al-Qur'an yang menawarkan konsep egalite (musawa, persamaan) dengan makna tekstual mengharuskan pemahaman kontekstual terhadap hadis ini. Sisi lain yang mengharuskan pemahaman kontekstual terhadap hadis ini ialah kandungan hadis yang cenderung primordialisme, yaitu mengkultuskan satu golongan atau suku saja sebagai pemegang otoritas dalam kepemimpinan Islam. Sedangkan salah satu konsep dasar politik Islam sebagai yang tercantum dalam alQur'an ialah negasi kultus individu dan golongan. Pemerintahan Islam yang dijalankan berdasarkan ketentuan dan hukum-hukum Allah tidak menghasilkan bentuk pemerintahan yang tirani. ${ }^{31}$ Negasi kultus individu, termasuk kultus etnis adalah suatu keharusan untuk menegakkan suatu sistim pemerintahan yang islami yang sesuai dengan hukum-hukum Tuhan. Dasar pemikiran seperti itulah yang mengharuskan hadis tentang kepemimpinan Quraisy di atas harus dipahami secara kontekstual agar tidak berbenturan dengan kondisi Islam nusantara yang terdiri dari berbagai suku bangsa.

Contoh lain hadis yang harus dipahami secara kontekstual agar tidak berbenturan dengan kondisi umat Islam nusantara adalah hadis yang mengatakan bahwa "Tidak akan berjaya suatu kaum yang menyerahkan

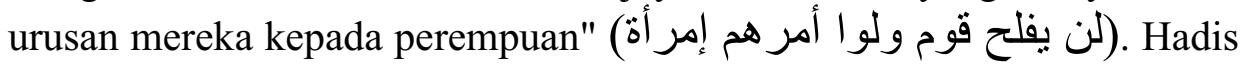
yang diriwayatkan oleh Imam Bukhari itu dapat dilihat sebagai berikut:

${ }^{30}$ Lihat Dewan Redaksi Ensiklopedi Islam, Ensiklopedi Islam, Vol II (Cet. II; Jakarta: Ichtiar Baru - Van Hoeve, 1994), h. 205.

${ }^{31}$ Lihat Abd. Muin Salim, Konsepsi, h. 189-190. 


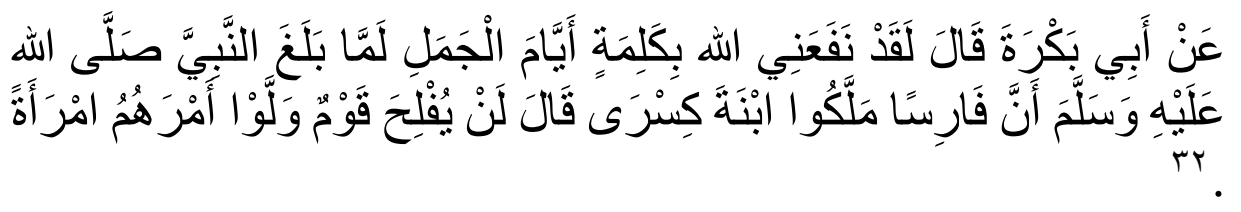

'Dari Ab- Bakrah berkata Allah telah memberi manfaat kepadaku dengan satu kalimat pada hari terjadinya Perang Jamal, yaitu ketika sampai berita kepada Nabi saw. bahwasanya Persia telah diperintah oleh puteri Kisra. Nabi bersabda: "Tidak akan berbahagia suatu kaum yang dipimpin oleh perempuan".

Hadis yang tercantum dalam berbagai kitab hadis mu'tabar ini baik sanad maupun matannya semuanya sahih. Walaupun demikian sering dipahami secara sempit dan keliru, sehingga dijadikan legitimasi ketidakbolehan wanita memegang jabatan sebagai kepala negara. Pemahaman terhadap hadis ini harus memperhatikan kondisi dan latar belakang sosial budaya Arab dan sejarah suksesi di Persia ketika hadis ini dikemukakan oleh Nabi. Sebab, ternyata hadis ini diucapkan Nabi ketika mendengar berita tentang proses suksesi yang terjadi di Persia, yaitu ketika Burawan binti Kizra bin Barwaiz yang masih berusia belia diangkat menjadi ratu menggantikan ayahnya. ${ }^{33}$

Dalam sejarah sosiologis-kultural, pada saat itu perempuan cenderung diposisikan sebagai manusia kelas dua dari laki-laki, sehingga lahirlah persepsi hanya sekedar pelayan dan pelengkap. Hal ini bisa dilihat dari kedudukan perempuan pada masa Jahiliyah yang tidak mempunyai arti fundamental. Bahkan, kadang disamakan dengan barang yang bisa diwariskan kepada anak-anaknya sendiri. Warisan ini diduga kuat mempengaruhi image terhadap distorsi kedudukan dan peran perempuan sampai saat ini dalam berbagai kehidupan publik termasuk wilayah politik yang dianggap sebagai wilayah kompotensi laki-laki.

Subordinasi peran perempuan masih banyak terjadi, baik dalam kalangan keluarga maupun dalam kehidupan publik, khususnya wilayah politik. Sejumlah persepsi negatif dalam masyarakat yang ditautkan pada diri perempuan masih kuat, seperti perempuan sangat lemah, emosional, dan irrasional sehingga perannya hanya cocok dalam bidang domestik

${ }^{32}$ Lihat Imam al-Bukhari, op. cit, juz V: 160, VIII: 434, Abu 'Abdullah al-Hakim alNaysaburi, al-Mustadrak 'Ala al-Sahihaayn (Beirut: Maktabat al-Ma ' b-'at al-Islamiyah, t.th.), juz III: 118-119, IV: 291.

33 Lihat Asbab Wurud al-Hadis, h. 82-84. 
(mengurusi dapur, menata ranjang, dan mengurusi anak) dan tidak layak menjadi seorang pemimpin, bahkan tidak jarang persepsi ini dilegitimasi dengan merujuk dan menganggap sebagai pesan teologis..

Riffat Hasan, ${ }^{34}$ mengatakan bahwa adanya distorsi atau pembatasan peran perempuan dalam kehidupan publik disebabkan karena sejumlah image yang dibangun mengenai sikap negatif terhadap perempuan termasuk bias jender ${ }^{35}$ dalam masyarakat muslim tidak jarang didasarkan dari pemahaman teologis, yang melahirkan kecendrungankecendrungan yang bersifat misoginis.

Ketika terjadi suksesi di Persia, derajat wanita sangat rendah. Mereka sama sekali tidak dipercaya untuk mengurus kepentingan masyarakat umum terlebih-lebih menjadi pemimpin negara. Opini umum hanya laki-laki yang bisa memimpin dan mengurus negara. Keadaan seperti itu tidak hanya terjadi di Persia, bahkan meliputi seluruh Jazirah Arab. Islaam datang mengubah posisi perempuan. Mereka diberi hak kehormatan dan kewajiban serta tanggung jawab baik terhadap diri, masyarakat maupun negara. ${ }^{36}$ Dalam kondisi yang demikian Nabi dengan kearifan yang ada padanya menyatakan bahwa bangsa yang menyerahkan masalah-masalah kemasyarakatan dan kenegaraan kepada wanita tidak akan sukses. Ketidaksuksesan Persia di bawah kendali seorang wanita yang diramalkan Nabi bisa juga dilihat dari segi usia Burawan binti Kizra yang ketika suksesi masih sangat muda, sehingga praktis eksistensinya hanya sebagai simbol pemerintahan.

Dilihat dari segi asbab al-wurud-nya, Ibn Hajar al-Asqalani, dalam Fath al-Bari, menjelaskan bahwa hadis tersebut bermula dari kisah Abdullah Ibn Hadzafah. Terdapat laporan dari kurir Rasulullah, yang menyampaikan surat ajakan masuk Islam kepada Kisra Anusyirwan, penguasa Persia yang beragama Majusi. Ajakan tersebut ditanggapi sinis

34Riffat Hasan - Fatimah Mernissi, Setara Dihadapan Allah: Relasi Laki-Laki dan Perempuan dalam Tradisi Islam Pasca Patriarkhi. Terjemahan Team LSPPA, (Cet III, LSPPA-Yayasan Prakarsa: Yokyakarta, 2000), h. 48-49.

35Pengertian jender dalam hal ini adalah seperangkat sikap, peran, tanggungjawab, fungsi, hak, dan perilaku yang melekat pada diri laki-laki dan perempuan akibat bentukan budaya atau lingkungan masyarakat tempat manusia itu tumbuh dan dibesarkan. Dengan kata lain, jender adalah suatu konsep yang mengacu pada peran-peran dan tanggungjawab laki-laki dan perempuan sebagai hasil konstruksi sosial yang dapat diubah sesuai dengan perubahan zaman. Lihat Musda Mulia, "Pengantar" dalam Musda Mulia dan Marzani Anwar (Editor), Keadilan dan Kesetaraan Jender Perspektif Islam, (Cet. I; Tim Pemberdayaan Perempuan Depag RI: Jakarta, 2001), h. XII-XIII.

36 Lihat Ahmad Amin, Tahrir al-Mar'ah, (Kairo: Dar al-Ma'rifah, t.th.), h. 25. 
dengan merobek-robek surat Nabi. Ketika itu Nabi saw. berdoa kepada Allah swt. agar kerajaan itu dihancurkan sehancur-hancurnya. Allah swt. mengabulkan doa Rasul sehingga negeri itu mengalami perang saudara. Pada suatu saat, tak lama setelah merobek surat dari Rasul, Kisra Anusyirwan dibunuh oleh anak laki-lakinya. Anak ini kemudian juga membunuh saudara-saudaranya. Lalu ia menjadi raja, dan akhirnya mati diracun. Ketika itulah kekuasaan kerajaan berada di tangan anak perempuannya yang bernama Bahran. Mendengar realitas politik negeri Persia seperti demikian, Rasul berkomentar: "lan yuflihu qawmun wallaw amrahum imratan". Komentar Rasul ini sangat argumentatif. Di samping akibat dari doa Rasul yang dikabulkan Allah SWT. sebelumnya, juga karena kafabilitas Bahran lemah di bidang kepemimpinan. ${ }^{37}$

Dengan demikian, hadis tersebut hanya berlaku untuk kasus tersebut, bukan bagi kasus lain. Karena itu, M. Quraish Shihab, seorang ulama kontemporer, yang memahaminya secara kontekstual dengan tegas menulis: "Jadi sekali lagi hadis tersebut di atas ditujukkan kepada masyarakat Persia ketika itu, bukan terhadap semua masyarakat dan dalam semua urusan". ${ }^{38}$

Senada dengan itu, Muhammad al-Ghazali mengatakan bahwa munculnya hadis ini karena ketika itu negeri Persia sedang berada diambang kehancuran menghadapi serangan bertubi-tubi oleh pasukan Islam. Sedangkan negeri itu masih dipimpin dengan sistem monarkhi dan otoritas, tidak mengenal sistem musyawarah bahkan di anatara keluarga istana saling menyingkirkan untuk merebut kekuasaan. Ketika pasukan Persia dipaksa mundur dan wilayah semakin menyempit sebenarnya masih ada kemungkinan untuk menyerahkan kepemimpinan kepada seorang jenderal, yang piawai yang mungkin dapat menghentikan kekalahan demi kekalahan. Tetapi paganisme politik yang telah menjadikan rakyat dan negara berbagi harta waris yang diterimakan kepada seorang perempuan muda yang belum tahu benar tentang politik. Hal itu yang menandakan negeri Persia sedang menuju kehancuran. Dengan kata-kata bijaknya Nabi berkomentar tentang peristiwa yang dialami oleh negeri Persia itu dengan mengungkapkan hadis di atas. ${ }^{39}$

Dengan pendekatan kontekstual tersebut, mayoritas umat Islam di nusantara berkesimpulan bahwa perempuan boleh menjadi seorang

37Lihat Ibn Ali Ibn Hajar al-Asqalani, op. cit., h. 56.

38Muhammad Quraish Shihab, Wawasan al-Quran (Bandung: Mizan, 1996), h. 314.

39 Syekh Muhammad al-Ghazali, op. cit., h. 136. 
pemimpin Negara. Adapun kelompok yang melarang kaum perempuan untuk terlibat dalam dunia publik, seperti hak politik untuk menjadi pemimpin, dengan mendasarkan kepada hadis di atas, adalah mereka dengan pemahaman tekstualistik-literalistik, karena tidak mempertimbangkan aspek historisitas (latarbelakang kemunculan, sabab al-wurud) hadis tersebut.

\section{Kesimpulan}

Akhir-akhir ini muncul istilah Islam Nusantara. Istilah tersebut diyakini lahir karena adanya pemahaman terhadap teks-teks keagamaan dengan mempertimbangkan kondisi masyarakat Islam Indonesia. Pemahaman tersebut dikenal dengan istilah kontekstual. Pemahaman kontekstual adalah upaya yang dilakukan sebagai salah satu ijtihad dalam menelaah kandungan yang dicakup oleh suatu matan hadis. Hal itu dilakukan jika ada suatu hadis tampak ketidak sesuaiannya dengan keadaan suatu masyarakat atau kurun waktu tertentu. Hadis tentang pemimpin itu dari Suku Quraisy dan hadis tentang tidak akan berjaya suatu kaum jika kepemimpinan itu diserahkan kepada perempuan adalah contoh betapa sulitnya diterapkan di Indonesia jika hanya dipahami secara tekstual dan tidak dipahami dengan pendekatan kontekstual.

Di Indonesia, banyak hadis yang memerlukan penjelasan (syarah) baru agar mampu menyingkap berbagai hakikat yang dikandung, dengan menggunakan bahasa yang populer dan sejalan dengan logika masa kini, agar lebih mudah mencapai tujuan. Oleh karena itu, para pengkaji Islam, khususnya di Indonesia dituntut untuk siap mengantisipasi munculnya masalah-masalah aktual yang berkembang dalam masyarakat. Hal itu mencerminkan betapa elastisnya prinsip dan metode ajaran Islam khususnya dalam bidang mu'amalah dan hubungan sosial, karena boleh disesuaikan dengan perkembangan dan kepentingan manusia yang senantiasa berubah sesuai tuntutan waktu dan tempat.

Jika Al-Quran telah ditafsirkan dengan memakai sejumlah disiplin ilmu sehingga terasa mampu berbicara langsung kepada rasionalitas masa kini, maka disayangkan bahwa kitab-kitab hadis belum beruntung mendapat penulis-penulis syarah (penjelasan dan komentar) yang menguasai sekaligus memadukan antara pemahaman ulama-ulama tradisional dan konsep-konsep pembaharuan masa kini.

Itulah sebabnya, rumusan-rumusan baru, pendekatan-pendekatan kontemporer, bahkan uraian aktual kontekstual harus diupayakan dan 
diprogramkan, mengingat perubahan cara berpikir manusia era tegnologi modern, tidaklah sama dan sebangun dengan cara berpikir manusia era pra-scientific agraris. Setidaknya, bahasa dan pola pikir yang digunakan sudah harus disesuaikan dengan muatan pengalaman manusia masa kini dan di sini.

\section{DAFTAR PUSTAKA}

Abdullah, Taufik. 1987, Islam dan Masyarakat, Jakarta; P3ES,.

Aqqad, Abbas, 1969, Mahmud al- Abqariyyah Muhammad, t.tp.: Dar alHilal,.

Asqalani,y Syihab al-Din Ahmad bin 'Ali bin Hajar al-, Nuzhat al-Nasar Syarh Nukbat al-Fikr, Beirut: Dar al-Kutub, t.th.

Azami,M.M,1977, Studies In Hadith Methodology and Literature, Indianapolis: Islamic Teaching Ceantre,.

Azami,M.M, 1994, "Studi in Early Hadith Literature", terjemahan Ali Mustafa Yaqub dengan judul Hadis Nabawi dan Sejarah Kodifikasinya, Jakarta: Pustaka Firdaus,.

Azra Azyumardi. 2002, Islam Nusantara Jaringan Global dan Lokal, Bandung; Mizan Media Utama,.

Azra Azyumardi. 1996, Pergolakan Politik Islam: dari Fundmentalisme Modernisme Hingga Post-Modernisme, Jakarta: Paramadina, .

Bukhariy,Abu 'Abdillah Muhammad bin Ismail al- Sahih al-Bukhari, Indonesia: Maktabah Dahlan, t.th.

Buti, Said Ramadan, 1980, al- Figh al-Sirah,Beirut: Dar al-Fikr,.

Coser, Lewis A. dan Bernard Rosenberg (Eds), 1964, Social Theory $\left(2^{\text {nd }}\right.$ Edition: New York: The mAcMillan Company.

Daud, Abu Muhammad al-Sijistani al-Azadiy, Sunan Abu Daud, Beirut: Dar al-Fikr, t.th.

Dewan Redaksi Ensiklopedi Islam,1994, Ensiklopedi Islam, Jakarta: Ichtiar Baru - Van Hoeve.

Djadjadiningrat, 1963, P.A. Hosein "Islam di Indonesia", dalam Kennet Morgan, ed., Islam Djalan Mutlak, terj. Abu Salamah, ddk. Djakarta : PT. Pembangunan. 
Gazali,Muhammad al- 1993, "al-Sunnah al-Nabawiyyah Bain Ahl al-Fiqh wa Ahl al-Hadis" terjemahan Muhammad al-Baqir dengan judul Studi Kritis atas Hadis Nabi Saw. Bandung: Mizan.

Hanbal, Abu 'Abdillah Ahmad bin, 1978, Musnad Ahmad bin Hanbal, Beirut: al-Maktabat al-Islami.

Haq, Mahmudul 'Abd al-Rahman al-Kawakibi (1854-1902): 1964-1965, A Study in Transition from Islamic Revivalism to Arab Nationalism, Bulletin Islamic Studies Aligarh University.

Hasan Riffat - Fatimah Mernissi, 2000, Setara Dihadapan Allah: Relasi Laki-Laki dan Perempuan dalam Tradisi Islam Pasca Patriarkhi. Terjemahan Team LSPPA, LSPPA-Yayasan Prakarsa: Yokyakarta.

Haykal, Muhammad, Hayat Muhammad, 1968, Kairo: Maktabat al-Nahdat al-Misriyah.

Hitty, Philip K. 1974, Histori of The Arabs, London: The MacMillan Press,.

Ismail,M. 1988, Syuhudi,Kaedah Kesahihan Sanad Hadis: Telaah dan Tintauan Kritis dengan Pendekatan Ilmu Sejarah, Jakarta: Bulan Bintang.

Ismail,M. Syuhudi, 1994, Hadis Nabi Yang Tekstual dan Kontekstual: Telaah Ma'ani al-Hadis tentang Ajaran Islam yang Universal, Temporal dan Lokal, Jakarta: Bulan Bintang.

Izutsu, Toshihiko, 1966, Ethico Religious Concept in the Koran, Montreal: McGill University Press.

Maarif, Ahmad Syafii, 1997, "Pendidikan Islam dan Proses Pemberdayaan Bangsa" dalam Muslih Usa dan Aden Wijdan SZ (penyunting), Pendidikan Islam dalam Peradaban Industrial, Yogyakarta: Aditya Media.

Madjid,Nurcholis, 1993, Mencari Formula Peran Umat Islam dalam Harian Jawa Pos, 10 Februari.

Muhajir, Noeng. 1998, Metodologi Penelitian Kualitatif, Yogyakarta: Rake Sarasin.

Muhibbin, 1996, Hadis-Hadis Politik, Yogyakarta: Pustaka Pelajar. 
Mulia, Musda dan Marzani Anwar (Editor), 2001, Keadilan dan Kesetaraan Jender Perspektif Islam, Tim Pemberdayaan Perempuan Depag RI: Jakarta.

Qardawi,Yusuf al- 1995, “al-Khasa al-'Ammah li al-Islm” terjemahan Rofi Munawwar dan Tajuddin dengan judul Karakteristik Islam; Kajian Analitik, Surabaya: Risalah Gusti.

Qasimi, Jamal al-Din al- 1979, Qawa'id al-Tahdis min Funun Mustalah al-Hadist,Beirut: Dar al-Kutub al-'Ilmiyyah.

Rabbath, Edmund. 1937, Unit Syrienne et Devenir Arabe, Paris, t.p.

Rahman, Asmuni A. 1976, Qaidah-Qaidah Fiqih,Jakarta: Bulan Bintang.

Rahman, Fazlur, 1987, Metode dan Alternatif Neomednisme Islam, diterjemahkan oleh Taufik Adnan Amal dari berbagai artikel Fazlur Rahman yang Berbahasa Inggris, Mizan: Bandung.

Salih, Subhi al- 1977, 'Ulum al-Hadis wa Mustalahuhu, Beirut: Dar al'Ilm Li al-Malayin.

Schumpeter, Joseph. 1955, Imperialism and Social Classes, New York: Meridian.

Shihab, Muhammad Quraish, dalam Muhammad al-Gazali, 1993, "alSunnah al-Nabawiyyah Bayn Ahl al-Fiqh wa Ahl al-Hadis", diterjemahkan ke dalam bahasa Indonesia oleh Muhammad alBaqir dengan judul Studi Kritis Atas Hadis Nabi Antara Pemahaman Tekstual dan Kontekstual, Bandung: Mizan.

Shihab, Muhammad Quraish, 1987, “Tafsir Kontekstual itu mutlak diperlukan”, Panji Masyarakat, No. 456, Jakarta, 21 Juli.

Shihab, Muhammad Quraish, 1996,Wawasan al-Quran, Bandung: Mizan.

Siba'i, Mustafa al-, 1976, al-Sunnah wa Makanatuha fi Tasyri' al-Islam (Beirut: al-Maktab al-Islami)

Sunanto, Musyrifah. 2010, Sejarah Peradaban Islam Indonesia, Jakarta: Raja Grafindo Persada.

Syaltut, Mahmud. 1966, Islam Aqidah wa Syari'ah, Kairo: Dar al-Qalam.

Tahhan, Mahmud, Taisir Mustalah al-Hadis, 1972, Beirut: Dar Alquran Alkarim. 
Watt, William Motgomery, 1953, Muhammad at Mecca, London: Oxford Universiry Press.

Yusuf, Mundzirin, 2006, dkk. Sejarah Peradaban Islam di Indonesia, Yogyakarta: Penerbit Pustaka. 